STUDI

FRANCESI

\section{Studi Francesi}

Rivista quadrimestrale fondata da Franco Simone

169 (LVII | I) | 2013

LA RÉVOLUTION SUR SCÈNE a cura di Pierre Frantz, Paola Perazzolo, Franco Piva

\title{
Saints ermites en Limousin au XII siècle, traduction et présentation par Michel Aubrun
}

\section{G. Matteo Roccati}

\section{OpenEdition}

\section{Journals}

Édition électronique

URL : http://journals.openedition.org/studifrancesi/3326

DOI : 10.4000/studifrancesi.3326

ISSN : 2421-5856

Éditeur

Rosenberg \& Sellier

\section{Édition imprimée}

Date de publication : 1 avril 2013

Pagination : 148

ISSN : 0039-2944

\section{Référence électronique}

G. Matteo Roccati, «Saints ermites en Limousin au xII siècle, traduction et présentation par Michel Aubrun », Studi Francesi [En ligne], 169 (LVII | I) | 2013, mis en ligne le 30 novembre 2015, consulté le 18 septembre 2020. URL : http://journals.openedition.org/studifrancesi/3326 ; DOI : https://doi.org/ 10.4000/studifrancesi.3326

Ce document a été généré automatiquement le 18 septembre 2020.

\section{(c)}

Studi Francesi è distribuita con Licenza Creative Commons Attribuzione - Non commerciale - Non opere derivate 4.0 Internazionale. 


\title{
Saints ermites en Limousin au XII siècle, traduction et présentation par Michel Aubrun
}

\author{
G. Matteo Roccati
}

\section{RÉFÉRENCE}

Saints ermites en Limousin au XII siècle, Traduction et présentation par Michel AUBRUN, Turnhout, Brepols, 2009 («Miroir du Moyen Age»), pp. 304.

1 Le volume contient la traduction française des Vies d'Etienne de Muret, de Geoffroy du Chalard, de Gaucher d'Aureil et d'Etienne d'Obazine (pp. 13-287; traduction établie d'après les éditions des textes latins respectivement par J. Becquet, 1968; A. Bosvieux, 1862; J. Becquet, 1963; M. Aubrun, 1970). Une brève introduction présente les quatre figures. Le volume comporte également une bibliographie (pp. 15-17), une carte et les index des noms de personnes, des noms de lieux, analytique et scripturaire (pp. 289-303). 